\section{LIFE CYCLE ASSESSMENT ANALYZING WITH GABI SOFTWARE FOR FOOD WASTE MANAGEMENT USING WINDROW AND HYBRID COMPOSTING TECHNOLOGIES}

Rozieana Abua, Muhammad Arif Ab Aziza,b, Che Hafizan Che Hassanc, Zainura Zainon Noora,c*, Rohaya Abd Jalild

aSchool of Chemical and Energy Engineering, Faculty of Engineering, University Technology Malaysia, 81310 UTM Johor Bahru, Johor, Malaysia

bCentre of Hydrogen Energy, Institute of Future Energy, University Technology Malaysia, 81310 UTM Johor Bahru, Johor, Malaysia cCentre for Environmental Sustainability and Water Security (IPASA), Research Institute of Sustainable Environment (RISE), University Technology Malaysia, 81310 UTM Johor Bahru, Johor, Malaysia

dReal Estate Department, Faculty of Built Environment and Surveying, University Technology Malaysia, 81310 UTM Johor Bahru, Johor, Malaysia
Article history

Received

20 June 2021

Received in revised form

2 September 2021

Accepted

15 September 2021

Published Online

20 October 2021

*Corresponding author zainurazn@utm.my

\begin{abstract}
Graphical abstract

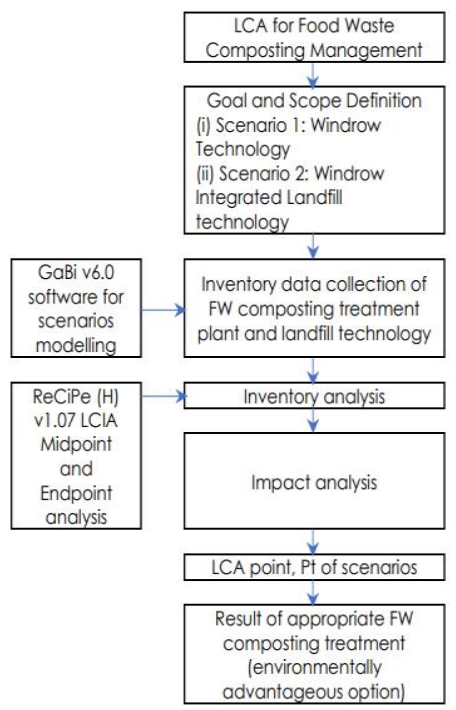

Abstract

The use of composting technologies to treat food waste (FW) now represents an environmentally friendly form of waste treatment, in which organic matter can decompose biologically. However, the damaging emissions of composting technologies for FW treatment vary, thus a life cycle assessment (LCA) approach is often used to certify the quality of the decision-making process. This study quantifies and compares the environmental impact of two scenarios in Malaysia: windrow and hybrid composting (windrow integrated with a landfill) technologies. The scenario modeling was performed via GaBi v6.0 software using 1 ton of pre-treated FW as a functional unit, with the analysis based on the ReCiPe (H) v1.07 characterization method. The midpoint results revealed that windrow composting technology has a lower environmental impact and is an environmentally friendly option compared to hybrid technology. Treating FW in a windrow scenario has relatively low power requirements for operation with the added advantageous properties of compost production, and a substantial reduction in the distances transferred by the road. The hybrid scenario had the largest negative environmental impact in all categories, such as climate change $(1.45 \mathrm{E}+03 \mathrm{~kg} \mathrm{CO} 2 \mathrm{eq})$, and ozone depletion (4.39E-09kg CFC-11 eq) because of the energy-intensive waste collection and treatment activities it needs, and with no landfill gas filtration. Finally, based on the single score synthesis, windrow is considered as an appropriate treatment with the avoidance of Resource Depletion $(6.61 \mathrm{E}+02 \mathrm{Pt})$. This study provides valuable insights for policy-making groups to help predict the environmentally preferred choice of $\mathrm{FW}$ management technologies in a particular area, resulting in improved environmental management sustainability.
\end{abstract}

Keywords: Decision making, food waste management, greenhouse gas emissions, Life Cycle Assessment, windrow composting technology 


\begin{abstract}
Abstrak
Penggunaan teknologi pengkomposan bagi merawat sisa makanan (SM) kini mewakili satu bentuk rawatan sisa mesra alam, di mana bahan organik dapat terurai secara biologi. Namun pelepasan teknologi kompos yang merosakkan untuk rawatan SM berbeza-beza, pendekatan penilaian kitaran hayat (LCA) sering digunakan untuk mengesahkan kualiti proses pengambilan keputusan. Kajian ini mengukur dan membandingkan kesan persekitaran dari dua senario di Malaysia: teknologi windrow dan pengkomposan hibrid (windrow bersepadu dengan tapak pelupusan). Pemodelan senario dilakukan melalui perisian GaBi v6.0 menggunakan 1 ton SM yang terawat sebagai unit berfungsi, dengan analisis berdasarkan kaedah pencirian ReCiPe $(H)$ v1.07. Hasil titik tengah menunjukkan bahawa teknologi kompos windrow mempunyai kesan persekitaran yang lebih rendah dan mesra alam berbanding dengan teknologi hibrid. Merawat SM dalam senario windrow memerlukan tenaga yang rendah untuk operasi loji kompos dengan kelebihan penghasilan kompos, dan pengurangan jarak SM yang dipindahkan melalui jalan raya. Senario hibridisasi mempunyai kesan persekitaran negatif terbesar dalam semua kategori seperti perubahan iklim (1,45E $+03 \mathrm{~kg} \mathrm{CO} 2$ eq), dan penipisan ozon (4.39E-09kg CFC-11 eq) kerana tenaga intensif yang diperlukan bagi aktiviti pengumpulan dan rawatan sisa, dan tiada bio-penapisan gas bagi tapak pelupusan. Akhirnya, berdasarkan sintesis skor tunggal, windrow dianggap sebagai rawatan yang sesuai dengan penghindaran Penurunan Sumber Daya (6.61E + $02 \mathrm{Pt})$. Kajian ini amat berguna bagi membantu kumpulan membuat dasar meramalkan pilihan teknologi rawatan untuk pengurusan sisa yang boleh terurai secara biologi di kawasan tertentu, yang seterusnya menghasilkan peningkatan kelestarian pengurusan alam sekitar.
\end{abstract}

Kata kunci: Membuat keputusan, pengurusan sisa makanan, pelepasan gas rumah hijau, Penilaian Kitaran Hayat, teknologi kompos windrow

(C) 2021 Penerbit UTM Press. All rights reserved

\subsection{INTRODUCTION}

Food waste (FW), in particular, has triggered the attention of many stakeholders due to the possible consequences and would be advantageous to both nutrient production and energy recovery [1]. The FW diversion into composting now represents a form of environmental waste treatment, in which organic matter is decomposed biologically [2]. Composting can be further categorized into aerobic and anaerobic composting [3]. An aerobic is the composting process in the presence of oxygen that converts the decomposable organic component of waste into compost, a beneficial material that is frequently used to improve soil quality and provide nutrients for plants [2]. Aerobic composting can be done in the open, as in the aerated pile and windrow processes, or in closed in-vessel or container systems [3]. Aerobic windrow composting is a technology for producing compost that involves stacking biodegradable materials in long rows. It is best suited for larger-scale operations and is mostly utilized in agricultural treatment plants, where mechanical pile rotation is required. In-vessel composting is a bioreactor-like organic waste treatment device with regulated heat and ventilation flow [3, 4]. It produces fewer greenhouse gas (GHG) emissions than windrow and aerated pile composting due to its enclosed form, but rather it consumes more diesel and energy caused by the usage of compressor, mechanical turning, and heat up/chilling system. An anaerobic technology, on the other hand, operates in an oxygen-free environment, such as the Bokashi approach that uses inoculated bran to transform organic waste into compost through fermentation [3]. Approximately 2000 mega composting plants with an annual capacity of 22 million ton (Mt) of organic and green waste are constructed in Europe [5]. The most wastecomposting European Member States include Austria $(40 \%)$, Italy (34\%), the Netherlands (27\%), and Belgium (25\%) [6]. Presently, in Malaysia, several privatized real scale FW composting plants have used aerobic type windrow composting as managed by Sutera Folo, Tanah Sutera Developments Johor Bahru, and Folo Farm, Ban Foo Ulu Tiram Johor. Both FW composting plants are capable of handling almost 3-5 tons/day of FW. The Jalan Jeriau Fraser Hill Compost Centre, alternatively, employs a hybrid of the two systems; aerobic in-vessel at the first stage and windrow at the second, during the decomposition of FW. This method is known as two-stage composting (TSC). TSC is a technology that consolidates two different composting methods aimed at improving the final product quality, process effectiveness and reducing the biological influence of standard composting procedures [4].

Furthermore, numerous life cycle assessment (LCA) studies have demonstrated that composting is more advantageous, i.e., has fewer environmental impacts, than other organic waste disposal scenarios, such as landfill and incineration [7]. On the contrary, it must not be presumed to be definite and caution should be taken before any immediate conclusion can be made as to which FW disposal option is best suited to the 
environment. This is due to the fact that FW composting is associated with various methods of the process being carried out, and it still does not accurately represent the damaging emissions that cause global warming, ozone layer destruction, and resource loss due to the use of non-renewable resources [8]. Various composting processes can be harmful to the environment. For example, emissions of carbon dioxide $\left(\mathrm{CO}_{2}\right)$ from fossil fuels in the transport and processing equipment, and methane $\left(\mathrm{CH}_{4}\right)$, nitrous oxides $\left(\mathrm{N}_{2} \mathrm{O}\right)$, and ammonia $\left(\mathrm{NH}_{3}\right)$ emissions from methanogenic and denitrifying processes under anaerobic conditions exist throughout the composting process, resulting in malodor and increased GHG emissions [9-10].

Hence, by employing a quantifiable measurement, the LCA approach enables the quantification and comparison of environmental impacts throughout the phases of a composting treatment's life cycle, such as the acquisition of raw materials, treatment, transport, usage, and final disposal. Various studies have been conducted on decision support using LCA frameworks for FW aerobic windrow composting management. For instance, Yoshikawa et al. [11] concluded that the centralized composting scenario has the least impact, but the on-site (using composting equipment trash disposal SANYO GNS-50, treatment capability: $50 \mathrm{~kg}$ per day) scenario has the greatest climate change and eutrophication impacts, and the traditional (incineration + landfill) scenario has the greatest waste landfill impacts. Another study by Al-Rumaihi et al. [2] investigated windrow composting and anaerobic digestion (AD) mixed composting, and it was discovered that windrow composting had the greatest environmental evaluation impact on acidification $\left(9.39 \times 10^{-1} \mathrm{~kg} \mathrm{SO} 2 \mathrm{eq}\right)$. While the impact of $\mathrm{AD}$ combined with composting was significant in the category of human toxicity $(3.47 \times 10 \mathrm{~kg} 1,4 \mathrm{DB}$ eq). Abduli et al. [12] has also reported the aerobic windrow composting integrated landfill scenario had a higher environmental impact than the landfill scenario. As a result, its impact on mineral and fossil sources, but also the environment, is greater than that of a landfill.

Despite the fact that aerobic windrow composting is widely implemented, there is still a lack of adequate knowledge of the whole range of environmental impact scores generally utilized in LCA studies that are considered especially for FW treatment in the Malaysia scenario [8]. Besides, there is a scarcity of data on realscale aerobic composting applications, particularly for $\mathrm{FW}$, which is far more heterogeneous than agriculture waste [3]. The quality of FW is determined by a number of factors, including humidity, calorific value, compactness, ash substance, and the environment. This classifies them as possible candidates for different composting treatment procedures. It is crucial to analyze the composting processes for extracting value from FW. Since different aerobic windrow composting technologies vary in emissions and energy requirements, it is very important to use LCA as a systematic methodology for evaluating and ensuring the environmental viability of FW treatments, especially for geographical differences [1]. Selecting the appropriate $\mathrm{FW}$ composting management system can be difficult $[1,2]$. Therefore, the LCA methodology is especially useful when comparing the potential environmental impacts of two or more alternative options [2]. This paper thus assesses the environmental implications and advantages of two comparative methods of composting strategies: the windrow composting technology and hybrid windrow composting with landfill technology. Finally, this study may provide valuable insights for policy-making groups to help predict the environmentally preferred choice of FW management technologies in a specific area, resulting in improved environmental management sustainability.

\subsection{METHODOLOGY}

The LCA methodology was applied to perform an environmental evaluation of the propositioned waste management preferences in accordance with the ISO 14040 and ISO 14044 guidelines (Figure 1). It is divided into four steps: (1) goal and scope definition, (2) life cycle inventory, (3) impact and assessment of the life cycle, and (4) interpretation.

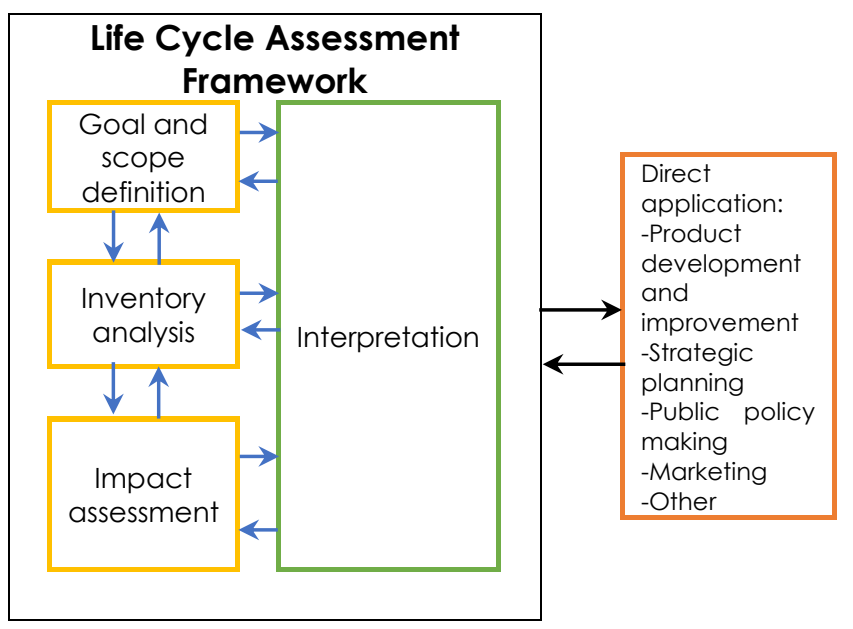

Figure 1 Framework for LCA in general [ISO 14040, ISO 14044]

LCA is a tool which attempts to address the problem of a comprehensive approach to environmental impact assessment. By ISO 14040, LCA is described as in this study context the "collection and assessment of the inputs, outputs, and possible environmental consequences of a treatment system during its life cycle". The treatment system is defined, which in this research perspective concentrates on the complete unit process system in the treatment life cycle. Besides, LCA may therefore be employed in various stages of life as a method to analyze the environmental load of the treatment. A holistic view of the load linked to a product or treatment service provided by a system will offer the most accurate image. To achieve holistic perspectives, it is necessary to choose which life cycle stages as well as upstream 
treatment activities to include. A consistent description of the system with well-defined system boundaries is therefore essential to guarantee a holistic view [8].

\section{Case Study}

A real-scale windrow composting plant located in Johor Bahru City, Malaysia, was chosen as a case study. This windrow composting plant is adjacent to residential area. A strategic partnership was formed between a local contractor and this composting plant, where the local contractor collected the FW from landed premises and business centres before supplying it to the composting plant to be treated as a compost fertilizer. This privatized composting facility is capable of processing almost 3-5 tons/day of FW and converting it into compost and using the compost produced to grow crops on the farm. The windrow plant also sells the compost as a dry fertilizer. The plant's operating hours are 6-9 hours per day.

\section{Goal and Scope Definition}

The aim of this LCA research is to evaluate the potential impacts on the environment and advantages of windrow composting and hybrid windrow composting with landfill technology, involving transport and operating stages for the production of compost products, as an alternative to handling biodegradable waste produced. The finding of this study is intended to provide the most optimal FW composting management technology based on the minimum level of contamination for Johor Bahru City Council Malaysia, with the possibility of making generalizations to other states as well. While the scope describes the study's complexity and thoroughness, in which there are a lot of decisions that this implies. The following things have been taken into account and stated: the system of treatment, the system function and operating unit, system limits, methods for allocation, methodology and types of environmental impact assessment, data and quality requirements, assumptions and restrictions.

\section{Functional Unit (FU)}

The FU shall define what the function or service offers in the treatment system. In all systems, 1 metric ton of FW is treated with equal amounts of $\mathrm{FW}$ of the same composition using windrow composting and integrated windrow composting combined landfill techniques. Therefore, it is required to establish a reference point for correlating the progression of inputs and outputs. In this study, the functional unit for comparing each composting system was established as the management of one ton of pre-treated FW.

\section{System Boundary and Descriptions of Scenarios Assessed}

The system boundary is known as the interface between the background and the foreground system.
The system boundary determines to what extent specialized data must be collected before generic data may be used. Clearly defined system boundaries are necessary to know what processes are to be included in the foreground system. For a successful LCA to be performed where uncertainty is reduced, the foreground processes should be based on specified data and the background processes are adequate for generic data. The assessment of system boundaries for this research is done from the cradle to the gate. The phrase "from the cradle to the gate" expresses that every step of the FW treatment's life cycle is covered in this LCA study: FW collection and transportation, FW treatment process, and bio fertilizer production, except product (biofertilizer) usage phase and management after disposal (reuse, recycling or final disposal). Generic value chain processes with relation to windrow functional specifications were adapted according to the real scale windrow composting plant at Johor Bahru. There is no consideration being assigned to wastewater treatment or compost disposal for agricultural uses. The compost produced by both scenarios is credited with the subtraction of mineral fertilizer. Input flows are materials, energy, and resources. Output flows are products, waste to treatment, as well as emissions to air, water, and soil as illustrated by Figure 2 .

Scenario 1 (WindrowComp) is the most commonly implemented practice at the community level. The technology is typically preferable for raw FW combined with some garden waste that has a moisture level of less than $60 \%$, since the higher presence of moisture interferes with the oxygen transmitted in composting. A windrow composting system will start with material collection and transportation to a composting center. Impurities such as plastics, glass bottles, and cans are screened for contaminant removal when the FW arrives at the facility. The production of quality compost comprises shredding of biomass waste, sufficient moisture and aeration, and frequent turning and mixing for 4 to 6 months (Windrow Composting Plant, Johor Bahru). Windrow composting entails arranging mixed biodegradable waste with bulking materials such as saw dust, sugarcane fiber waste, and so on in long, thin piles or lanes, which are referred to as windrow formations. The FW is then placed on the prepared base and covered with canvas. Canvas is lightly draped over the piles to avoid rainfall from soaking through and forming extra moisture. On a regular basis, the rows are turned using a turner to combine the composting matter, to enhance its permeability and humidity. The turning machine pulls the material from the windrow and then re-disperses it and mixes the material and converts it into a loose mixture. When the turner goes along the windrow, it removes stockpiled heat and gases, combines the ingredients, shatters big particles, and enables clean air to enter the compost. When necessary, water is added while turning to keep humidity at $50-60 \%$. If it is overly moist, it is necessary to turn it more often. The compost is then cured and left exposed for a further couple of weeks 
before the proper particle size is screened. Before releasing the compost on the market and to verify it conforms to the appropriate standards, a sample is generally obtained to assess the quality of the compost [2].

Scenario 2, the windrow composting combined with landfilling scenario (WindComp \& L), is similar to windrow composting, but combined with the current practice of landfilling of the solid fraction of digested matter. In this second scenario, windrow composting is used to treat $70 \%$ of the FW, while landfilling is used to treat the remaining $30 \%$. The composting treatment is done by the same composting plant (in the first scenario, a distance of $5 \mathrm{~km}$, one trip per day). The garbage from pre-treatment and post-treatment is deposited in a conventional landfill 45 kilometers away (about two trips per week). Landfills in this scenario have no system for landfill gas filtration.

\section{Life Cycle Inventory}

In this step, all extractions and emissions are classified and put on an inventory list that includes all inputs and outputs of the treatment systems examined (Table 1). Secondary data obtained from the Tanah Sutera Development Office (Johor Bahru), on-site observation, published scientific literature, such as Ghazvinei et al. [13], Mendes et al. [14], Johari et al. [15], and the GaBi Professional v6.0 database, were used for this analysis. The foreground data came from the owner's treatment plant, while the background data came from the generic GaBi Professional v6.0 database, which was used to model and evaluate the environmental burdens of all systems, windrow composting, and windrow plus landfill. The energy requirements are provided by Malaysia's national electrical system. Due to regional Malaysia data still lacking, this analysis assumes that manufacturing processes and inventory data for all scenario procedures are identical in Malaysia and other areas such as Singapore, Brazil, the State of Qatar, and Italy.

\section{Life Cycle Impact Assessment and Impacts Assessed}

The life cycle impact assessment (LCIA) is performed in the third phase of LCA research, wherein the data on elementary flows from the life cycle inventory (LCI) is converted into environmental impact scores. The LCIA evaluates the inventory in relation to the collection of different environmental inputs and outputs involved in the life cycle of a process. In particular, inventory data is categorized and translated into specific equivalence units for each classification of effect (e.g., global climate change, human pollution, acidification, etc.) to be summarized for each category of the indicator [19]. To measure the burden on the environment and advantages, the impact analysis was modelled and simulated using LCA software GaBi Professional v6.0 database and ReCiPe hierarchist $(\mathrm{H})$ v1.07, as the LCIA approach was chosen in this study. There are two mainstream ways to derive characterization factors, i.e., at the midpoint level and at the endpoint level. ReCiPe $(H)$ is built with 16 midpoint indicators, 15 endpoint indicators, and a single score of 3 points in its package software, and in this study, all the environmental impact scores have been included in the analysis.

Concerning the midpoint metrics, it relies on single environmental issues, such as climate change or acidification, and are known as problem-oriented methods. These features may not constitute an important environmental impact of the pollutants recorded in the life cycle inventory, but rather possible impact indicators. The conversion of midpoints to endpoints simplified the investigation of the LCIA's impacts. Endpoint modelling is primarily concerned with characterizing the intensity or implications of midpoint impacts. This endpoint characterization necessitates the modelling of all environmental parameters. Therefore, endpoint metrics, known as the damage-oriented approach, show environmental potential damage at three higher accumulation levels: (1) impact on human wellbeing, (2) biodiversity, and (3) scarcity of resources. In order to compose the single score indicator, various LCIA techniques, i.e., IMPACT 2002+, Ecological Scarcity 2006, and Ecoindicator $99(\mathrm{H})$, have different normalization and weighting variables, and these parameters have a considerable effect on the output of the single score. In spite of this, ReCiPe has been identified as the best endpoint technique since the characterization models are mature [20], [21].

Taking into consideration cultural perspectives (e.g., the Hierarchist, the Individualist, the Egalitarian), the hierarchist has been used in this study as it is predicated on time frame and other concerns about the most prevalent policy principles [19]. It utilizes the medium-term framework, e.g., a 100-year timeframe for global warming, GWP100. Besides, it's time perspective is a balance between the short and long term, its manageability can avoid many problems based on proper policy, and finally, the required level of evidence is based on the inclusion of consensus [19].

GaBi as a software tool is used to model and analyze both treatment scenarios, since GaBi offers the most detailed findings, based on its strong and extensive database. GaBi encompasses updated databases incorporating eco-invent, CML2001 and other recognized databases. GaBi has the best features with regard to the product's definition function and LCIA techniques used in the software, the user's capacity to alter databases integrated into the software, as well as detailed information and results presentation. Moreover, GaBi includes the latest ReCiPe technique developed in 2008 by RIVM and Radboud University, CML, and PRE' Consultants. 


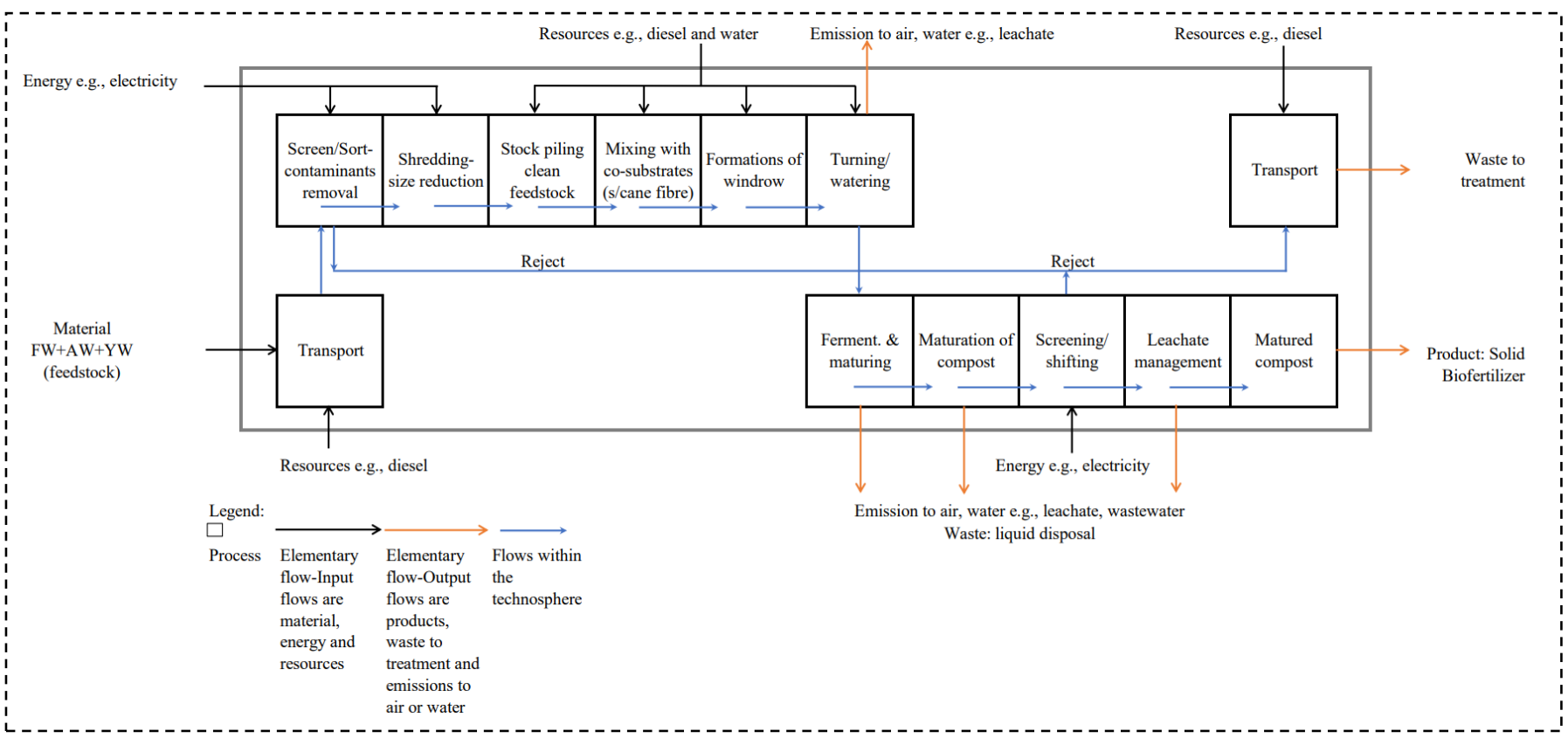

(a)

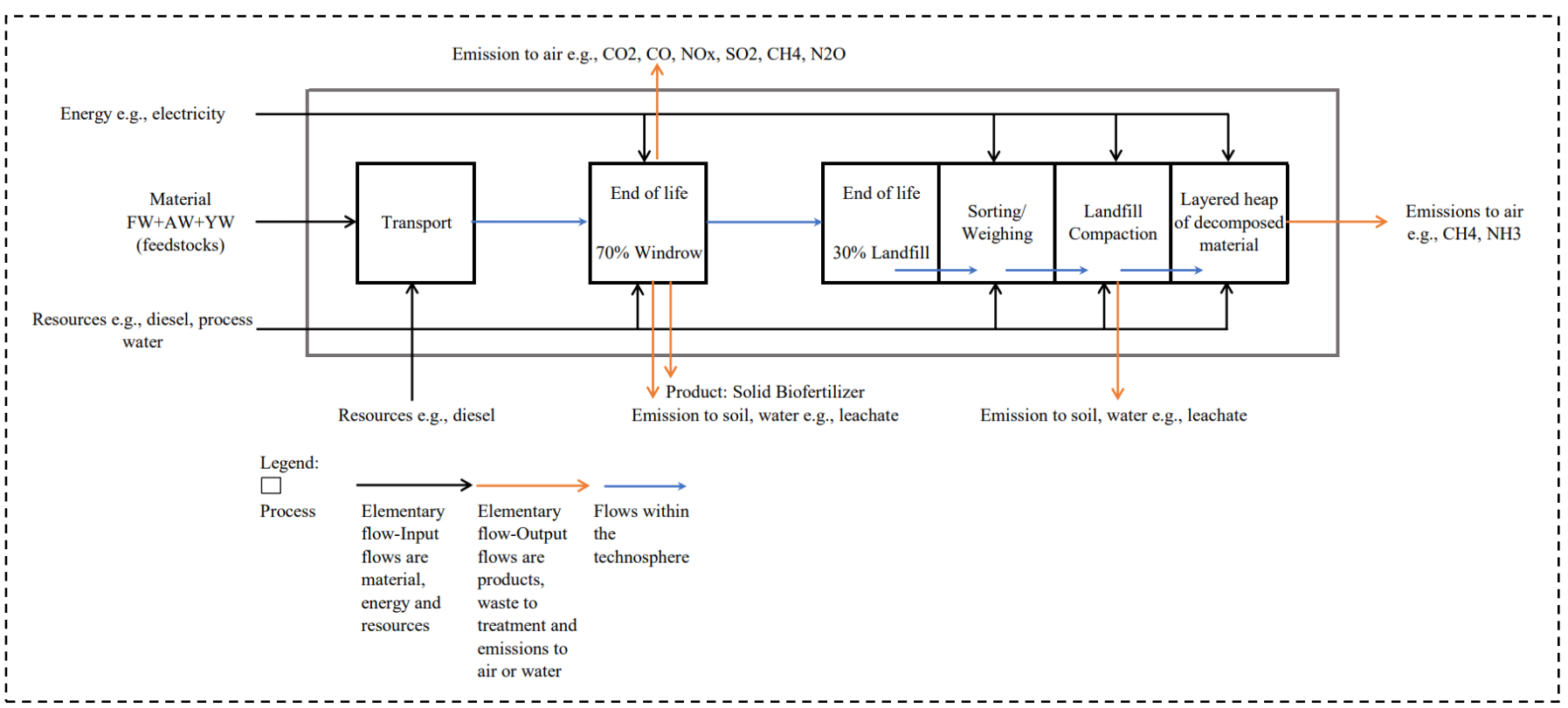

(b)

Figure 2 System boundaries for FW treatment (a) Windrow, and (b) Hybrid_Windrow combined Landfill 
Table 1 Summary of the inventory data for windrow composting and hybrid_windrow with landfilling scenarios. All quantities are based on 1 ton of compostable wastes

\begin{tabular}{|c|c|c|c|c|c|c|}
\hline \multirow[t]{2}{*}{ Waste treatment } & \multirow[t]{2}{*}{ Flow } & \multirow{2}{*}{$\begin{array}{l}\text { Windrow } \\
\text { composting }\end{array}$} & \multirow[t]{2}{*}{ Landfill } & \multirow{2}{*}{$\begin{array}{l}\text { Units } \\
\text { ( } t^{-1} \text { waste) }\end{array}$} & \multicolumn{2}{|c|}{ Source } \\
\hline & & & & & Windrow & Landfil \\
\hline \multicolumn{7}{|l|}{ Input } \\
\hline Material (feedstock) & $F W+G W+A W$ & 1 & & $\dagger$ & & \\
\hline \multirow{2}{*}{ Transportation } & Distance & 5 & 45 & $\mathrm{~km}$ & c & \\
\hline & Truck payload & 5 & 5 & $t$ & $\mathrm{i}$ & \\
\hline Energy consumption & Electricity & 110 & 667.4 & kWh & c & $f, h$ \\
\hline Water consumption & Tap water & 120 & 52 & $\mathrm{~kg}$ & $\mathrm{~b}$ & $\mathrm{~b}$ \\
\hline \multirow[t]{3}{*}{ Resources } & Diesel & 9.641 & 11.4 & । & $a, b$ & $g, h$ \\
\hline & Lubricant & 0.5 & - & i & a & \\
\hline & Anti-odour & 20 & - & । & a & \\
\hline \multicolumn{7}{|l|}{ Output } \\
\hline \multirow{13}{*}{ Emission to air } & $\mathrm{CH}_{4}$ & 14.55 & 37.849 & $\mathrm{~kg}$ & $a, b$ & $d$ \\
\hline & $\mathrm{CO}_{2}$ & 430 & 21.24 & $\mathrm{~kg}$ & a & $f, h$ \\
\hline & $\mathrm{CO}$ & 0.6 & 0.0236 & $\mathrm{~kg}$ & a & $\mathrm{h}$ \\
\hline & $\mathrm{N}_{2} \mathrm{O}$ & 0.1 & 0.002 & $\mathrm{~kg}$ & a & $f$ \\
\hline & $\mathrm{NH}_{3}$ & 10.04 & - & $\mathrm{kg}$ & $a, b$ & \\
\hline & $\mathrm{NO}_{x}$ & - & 0.25 & $\mathrm{~kg}$ & & $f, h$ \\
\hline & $\mathrm{HCl}$ & - & 0.006 & $\mathrm{~kg}$ & & $f$ \\
\hline & $\mathrm{HF}$ & - & 0.001 & $\mathrm{~kg}$ & & $\mathrm{f}$ \\
\hline & $\mathrm{H}_{2} \mathrm{~S}$ & 0.02 & 0.018 & $\mathrm{~kg}$ & $\mathrm{~b}$ & $\mathrm{f}$ \\
\hline & VOC & 36.5 & - & $\mathrm{kg}$ & a & \\
\hline & NMVOC & 0.01 & - & $\mathrm{kg}$ & $b$ & \\
\hline & $\mathrm{SO}_{2}$ & - & 0.0381 & $\mathrm{~kg}$ & & $f, h$ \\
\hline & Particles & - & 0.0074 & $\mathrm{~kg}$ & & $\mathrm{~h}$ \\
\hline \multirow[t]{14}{*}{ Emission to water } & $\mathrm{BOD}_{5}$ & 1964 & - & 9 & a & \\
\hline & COD & 6392 & - & $\mathrm{g}$ & a & \\
\hline & Phenol & 0.6 & - & $\mathrm{g}$ & a & \\
\hline & Free chlorine & 0.1 & - & 9 & a & \\
\hline & Sulphide & 3.9 & - & g & a & \\
\hline & $\mathrm{NH}_{3}$ & 2934 & - & g & a & \\
\hline & $\mathrm{PO}_{4}$ & 19.4 & - & g & a & \\
\hline & Total N & 3452 & 1003 & g & a & $f$ \\
\hline & Leachate & 0.28 & - & $t$ & b & \\
\hline & $\mathrm{Hg}$ & - & 1.4 & $\mathrm{mg}$ & & $\mathrm{e}$ \\
\hline & $\mathrm{Cd}$ & - & 0.06 & $\mathrm{mg}$ & & $\mathrm{e}$ \\
\hline & $\mathrm{Fe}$ & - & 35.1 & $\mathrm{mg}$ & & $\mathrm{e}$ \\
\hline & $\mathrm{Mg}$ & - & 1.6 & $\mathrm{mg}$ & & $\mathrm{e}$ \\
\hline & $\mathrm{Zn}$ & - & 1.33 & $\mathrm{mg}$ & & e \\
\hline Valuable materials & Compost & 0.8 & - & $t$ & c & \\
\hline
\end{tabular}

\subsection{RESULTS AND DISCUSSION}

This section highlights the environmental impact assessment for the two technologies evaluated relating to the management of the 1-ton FW. The results analyzed via the ReCiPe $(\mathrm{H})$ LCIA method present 16 midpoint indicators, 15 endpoint indicators, and a single score of 3 points. All the values have been recorded in Table 2 and Table 3. A positive value indicates an increased environmental load, whereas a negative value indicates a reduction in environmental pressure or an improvement in sustainability impact.

\section{Midpoint Assessment}

Table 2 summarizes the midpoint environmental impact scores for the treatment of 1-ton FW for the two cases considered. The results indicate that windrow composting has the greatest potential for environmental improvement in all areas. The highest reduction, such as in ozone depletion (ODP) (1.07E-09 kg CFC-1 1 eq), and human toxicity (HTP) $(5.51 \mathrm{E}+00 \mathrm{~kg}$ 1,4-DB eq) as well as in all ecotoxicity impacts (freshwater, terrestrial, marine), is found in windrow composting. However, hybrid scenario_windrow composting combined with a landfill poses significant negative environmental impacts in all categories, with the largest primary energy demand (PED) (9141.24 MJ). It is also found that both scenarios contribute to ionizing radiation (IRP), global warming (GWP) and water depletion (WDP), but the hybrid scenario significantly shows the highest contribution to IRP $(1.82 \mathrm{E}+03 \mathrm{~kg}$ U235 eq), followed by GWP $(1.45 \mathrm{E}+03 \mathrm{~kg} \mathrm{CO} 2 \mathrm{eq})$, and WDP $\left(1.38 \mathrm{E}+03 \mathrm{~m}^{3}\right)$ respectively. 
Table 2 Cumulative midpoint assessment of environmental impacts and inventory analysis of two technologies analyzed

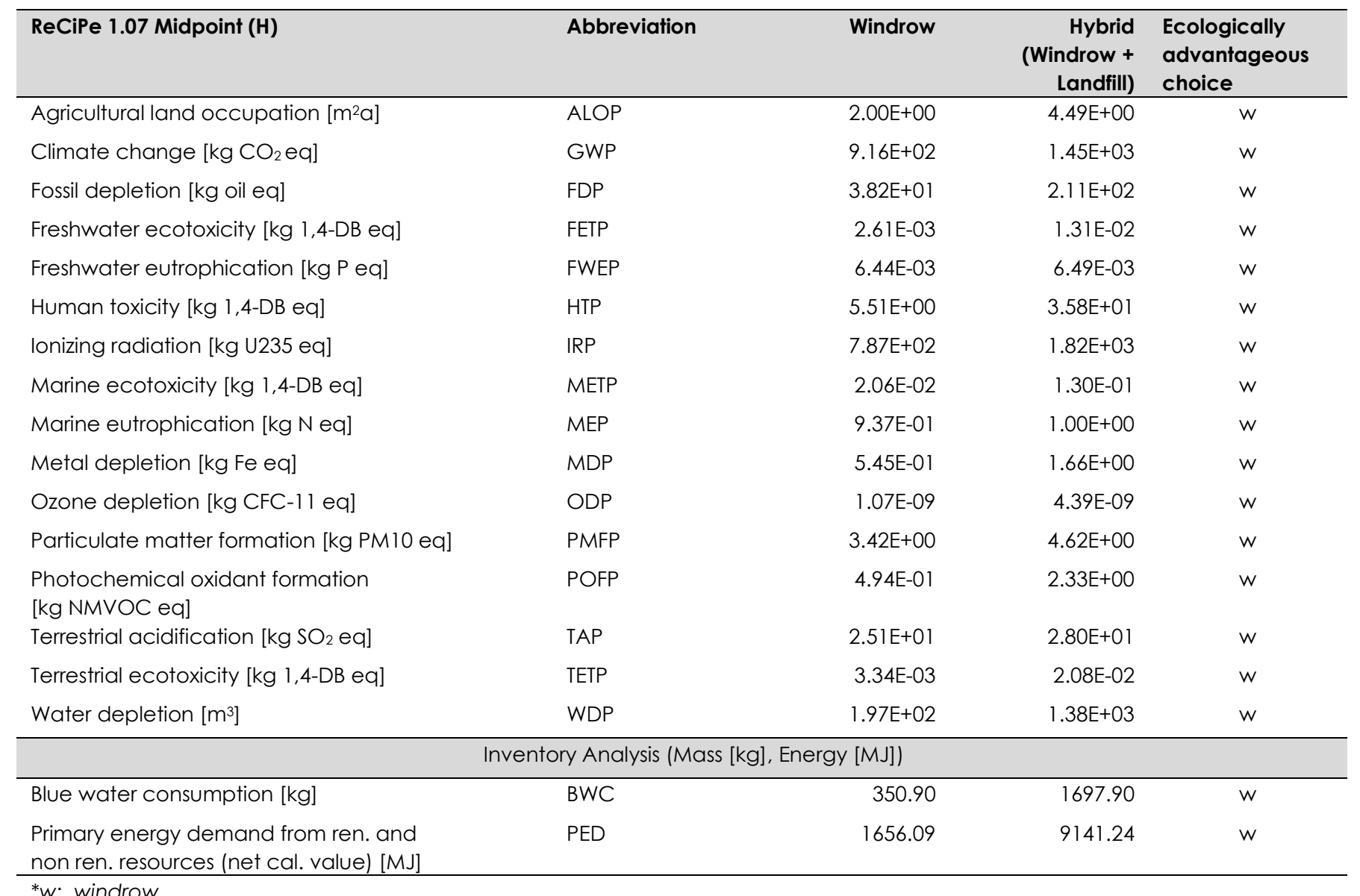

*w: windrow

Agricultural Land Occupation Potential (ALOP) and Water Depletion Potential (WDP)

According to the results in Table 2, aerobic windrow has demonstrated that it requires less area for agricultural land occupation (ALOP) $\left(2.00 \mathrm{E}+00 \mathrm{~m}^{2} \mathrm{a}\right)$. The hybrid windrow, in contrast, necessitates a large operational space and must be located far from populated areas. Another disadvantage of the hybrid scenario is that a large amount of water must be applied during the treatment process, as shown by the blue water consumption (BWC, $1697.90 \mathrm{~kg}$ ), resulting in an increased WDP $\left(1.38 \mathrm{E}+03 \mathrm{~m}^{3}\right)$.

\section{Global Warming Potential (GWP)}

GWP refers to the phenomenon of rising atmospheric temperatures that will have negative effects on the ecosystems and human health [19]. It should be noted that the first and second scenarios generate GWP impacts, which are detected more strongly in combined scenarios, particularly in GHG pollution inventories, which show an increase in the volume of these compounds released from waste treatment plants and transportation activities. $\mathrm{CO}_{2}, \mathrm{CH}_{4}$, and $\mathrm{N}_{2} \mathrm{O}$ emissions are the primary reasons for this increase. A fraction of these emissions could be reduced using low-cost biological methods like biofiltration. This was also evident in Abduli et al. [12], which indicated that the composting integrated landfill scenario had a higher environmental impact in most categories. Previous research has revealed that landfills contribute more to global warming than aerobic composting [6].

\section{Fossil Depletion Potential (FDP)}

The second scenario, unlike the first, involves a power-consuming procedure of around 9141.24 MJ per ton of garbage received. Thus, it was observed that the first scenario is recommended for minimizing fossil depletion (FDP) $(3.82 \mathrm{E}+01 \mathrm{~kg}$ oil eq) and primary energy demand (PED, 1656.09MJ). Fossil fuel was widely employed for power. Statistical evidence shows a reduction in the availability of fossil fuels which may readily be extracted, such as liquid oil [1, 6]. This does not mean that we face the end of fossil fuels, but that we need to utilize other lower-quality resources which require more energy to obtain. Operational procedures requiring electricity or fuel always maximize the total environmental impact 
resulting from the treatment operation, and this is the biggest contributor to the GWP.

\section{Terrestrial Acidification Potential (TAP)}

TAP is an acidification of soil or aquatic ecosystems phenomenon which leads to a fall in the system's acid neutralizing capacity and relates to the emission of acidifying compounds primarily caused by $\mathrm{NO}_{x}$ and $\mathrm{NH}_{3}$ emissions [19]. Due to the higher $\mathrm{NO}_{x}$ and $\mathrm{NH}_{3}$ generated in a hybrid scenario throughout the treatment process, windrow composting is the preferred acidification option. However, Al-Rumaihi et al. [2] argue that windrow composting has significantly higher environmental impacts across the majority of impact categories studied and has demonstrated a much more undesirable acidification impact, with approximately $90 \%$ resulting from FW collection and transportation, composting process, and final product transport.

Ecotoxicity Potential (Terrestrial, Fresh Water, and Marine)

Terrestrial ecotoxicity (TETP) is referred to as the consequences of toxic chemicals on terrestrial ecosystems such as forests and wetlands. Metals and chemicals released during the process treatment have the potential to cause soil degradation. Mercury $(\mathrm{Hg})$ has the highest ecotoxic consequences in composting plus landfill scenarios and is extremely dangerous, but due to its low concentration, it is less ecotoxic [12]. Meanwhile, the effects of toxic chemicals released into fresh water ecosystems such as lakes and rivers are referred to as fresh water ecotoxicity (FETP) and marine ecotoxicity (METP) affected the open ocean. In these categories of impact (TETP, FETP and METP), Scl windrow composting would seem to be the best.

\section{Human Toxicity (HTP)}

HTP assessments are related to permissible daily consumption and intake to human toxicity. The toxicity impact is separated into two: chemical cancer and chemical non-cancer effects. The unit is measured at 1-4-DB of $\mathrm{kg}$ equivalence. Included among the substances were heavy metals, toxic chemicals, and so forth. As per this study, almost $90 \%$ of landfill emissions contribute to HTP and it is observed that the Sc2_hybrid scenario is the least favourite in this category of impact $(3.58 \mathrm{E}+01 \mathrm{~kg} 1,4-$ DB eq).

\section{Particulate Matter Formation Potential (PMFP)}

Primary PMF represents particles emitted directly, e.g., by transportation or the activity of power stations. A complex combination of organic and inorganic chemicals, including $\mathrm{NO}_{x}, \mathrm{SO}_{x}, \mathrm{NH}_{3}$, semivolatile and volatile organic compounds (VOC), having a diameter smaller than $10 \mu \mathrm{m}, \mathrm{PM} 10$ creates concerns about health as it reaches the highest part of the respiratory tract and lungs [19]. Due to the fact of the energy-intensive waste collection and treatment activities that hybrid scenarios need, in this type of impact (PMF), the Sc2_hybrid scenario is the minimum favoured $(4.62 \mathrm{E}+00 \mathrm{~kg} P M 10 \mathrm{eq})$.

\section{Photochemical Oxidant Formation Potential (POFP)}

POFP indicates the response of the sun to anthropogenic airborne pollution that leads to the production of reactive chemicals (mostly ozone). This generates smog, a chemical substance which causes airborne illnesses and human disorders as well as habitat loss and agricultural harm. VOCs result in important human emissions, such as the use of organic solvents by vehicle traffic. $\mathrm{CO}$ is released with inadequate $\mathrm{O}_{2}$ supply from combustion activities. These include traffic on the roads and several kinds of incomplete fossil combustion [6, 19]. $\mathrm{NOx}$ is also released during transport through combustion processes. In the hybrid scenario, POFP is demonstrated as the worst. This is because the volumes carried, as well as the distance travelled by road to treatment facilities from the windrow plant to the landfill's final disposal site, have increased significantly, and these factors are also evident in previous research, such as in Righi et al. [6]. Windrow composting_Scl (4.94E-01 kg NMVOC eq) is shown to be the most desired in this area of impact.

\section{Eutrophication Potential (Fresh Water and Marine)}

Aquatic eutrophication (FEP) could be described as aquatic nutrient enrichment that leads to environmental problems regarding the physical and chemical composition of the receiving water bodies, while marine eutrophication (MEP) affects marine water bodies. The substances included were $\mathrm{NH}_{3}, \mathrm{P}$, $\mathrm{PO}_{4}$ etc., which most originated from emissions released by windrow process treatment, landfill and diesel usage. In these two categories of impact, Scl_windrow would appear to be the most favoured compared to Sc2_hybrid windrow combined with a landfill.

\section{Ozone Depletion Potential (ODP)}

It must be highlighted that the second scenario is largely responsible for the depletion of the ozone layer's impact, (4.39E-09 kg CFC-11 eq). The ODP increased UVB radiation intensity on the Earth's surface, causing damage to human health (i.e., skin cancer, immune system depression) and ecosystems (reduction in production of wood, crops and fish). Natural ozone depleting substances (ODS) such as $\mathrm{CH}_{4}, \mathrm{~N}_{2} \mathrm{O}, \mathrm{H}_{2} \mathrm{O}$, and halogenated substances are the main sources of ozone depletion [19]. The halogen compounds in the stratosphere are most likely derived from the use of very stable industrial halocarbon gases (e.g., spray cans, refrigerators) are found in landfill. This is because, in the majority of 
Malaysian landfills, mixed municipal solid waste (MSW) is deposited without being pre-treated [22]. Besides, the ODP problem is also anticipated in the treatment process, mainly because of the high-water requirements. In whole-scenario cases, the contaminants come primarily from background processes such as energy production for the treatment process and tap water.

\section{lonizing Radiation Potential (IRP)}

IRP is the term used to describe the harm done to human health as a result of the routine discharge of radioactive materials into the environment. A high dosage can result in visually spectacular radiation burns and/or quick death due to acute radiation syndrome. This category encompasses the generation of coal energy and other terrestrial sources, including natural radioactive elements found at the greatest levels of landfills in rock and soil, as can be seen in the hybrid scenario (1.82E+03

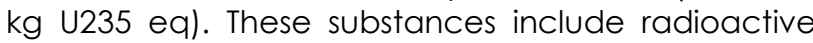
materials (i.e., radon, uranium, etc.), among others.

\section{Metal Depletion Potential (MDP)}

We decrease the quality of the remaining resources by mining minerals including zinc and lead (MDP). This is because the greatest resources are always obtained by human beings first, reducing the poorer quality resources for future generations. Resource harm will be experienced by future generations because they will have to expend more energy or effort to obtain other resources. The unit is $\mathrm{kg}$ of $\mathrm{Fe}$ equivalence. Included among the resources are ore, minerals, and so forth. In this impact category, the preferential FW treatment is Scl windrow composting (5.45E-01 kg Fe eq).

Subsequent to a functional unit of 1 ton of $\mathrm{FW}$ for a case study in Johor Bahru, Malaysia, research has found that windrow composting has a smaller environmental impact than hybrid windrow composting and landfill. The massive emissions in the hybrid scenario are produced as a result of impacts from the degradation of FW, which accounts for approximately $64 \%$ of the windrow treatment process, $35.9 \%$ of landfill, and $0.1 \%$ of transportation, particularly relating to GWP (Figure 3).
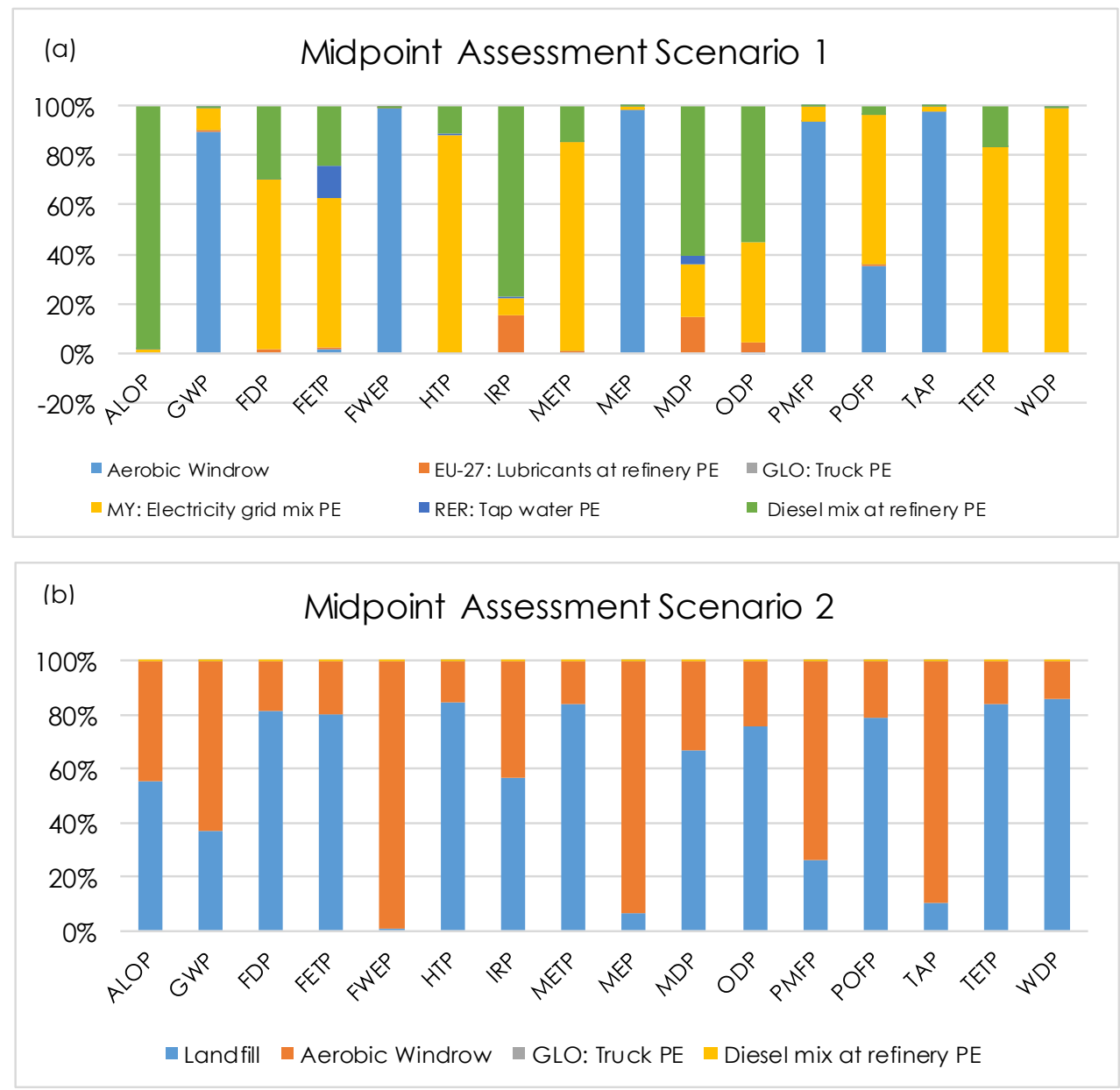

Figure 3 Midpoint assessment for (a) windrow; and (b) hybrid_windrow and landfill 
Single Score by Endpoints ReCiPe LCIA Methodology Analysis

Table 3 summarizes the final results. The second scenario is worse for FW treatment than the first relating to the fossil depletion category. In all cases, the overall damage from landfilling activities is far greater than the harm from the other sectors, followed by aerobic windrow process treatment. According to the findings in Abduli et al. [12], integrated composting with landfills is also the worst environmental scenario due to the lack of a system for collecting and manipulating gases used to generate electricity. The largest influence on climate change is caused by $\mathrm{CH}_{4}$ emissions from landfills. Landfilling, such as that employed in this research design, generates a significant amount of $\mathrm{NO}$ from road transportation and disposal site machinery. $\mathrm{NO}_{x}$ has the potential to impair breathing and increase the incidence of respiratory infectious diseases. Since there is no infrastructure for gas and leachate treatment in most Malaysian landfills, compounds that are harmful to the environment, such as $\mathrm{CO}$, $\mathrm{N}_{2} \mathrm{O}$, and $\mathrm{H}_{2} \mathrm{~S}$, have been identified in effluent and emissions [22]. Whereas the windrow composting integrated AD method used in a study conducted by Al-Rumaihi et al. [2] demonstrated the positive potential impacts and is the better environmental option due to the biogas recovery in this treatment technology. Despite the benefits of the first scenario, windrow practice is associated with significantly higher levels of human health risk and Al-Rumaihi et al. [2] emphasized that aerobic windrow has a substantial impact on these scenarios. According to recent research, mostly open composting systems such as windrows have disadvantages, the majority of which are associated with odour-emitting annoyances formed during the process, and pests' problems through opening the aerobic treatment area [6], [8]. Thus, the windrow needs effective mitigation strategies to overcome some of the drawbacks. This extensive improvement will enhance the aerobic windrow to be the most optimal FW composting management technology.

According to single-score comparisons (Figure 4), the integrated composting with landfill scenario causes significantly more harm to human health (3.26E-03 Pt) than the windrow scenario. Furthermore, its impact on mineral and fossil resource degradation (3.66E+03 Pt) and ecosystem quality damage (1.17E$05 \mathrm{Pt}$ ) is greater than that of the windrow scenario. As a result, the integrated scenario posed a greater environmental risk than the windrow scenario.

Table 3 Damage classifications for windrow and integrated windrow with landfill

\begin{tabular}{|c|c|c|c|}
\hline ReCiPe Endpoint (H) & Windrow & $\begin{array}{r}\text { Hybrid } \\
\text { (Windrow+ } \\
\text { Landfill) }\end{array}$ & $\begin{array}{l}\text { Ecologically favoured } \\
\text { alternative (Founded on } \\
\text { the lowest degree } \\
\text { damages rank) }\end{array}$ \\
\hline ReCiPe Endpoint $(\mathrm{H})$, Resources (overall impact, point [Pt]) & $6.61 E+02$ & $3.66 \mathrm{E}+03$ & \multirow{3}{*}{$\begin{array}{l}\text { 1-Windrow } \\
\text { 2-Windrow+Landfill }\end{array}$} \\
\hline Fossil depletion [\$] & $6.61 \mathrm{E}+02$ & $3.66 \mathrm{E}+03$ & \\
\hline Metal depletion [\$] & $8.85 \mathrm{E}-03$ & $5.45 \mathrm{E}-02$ & \\
\hline ReCiPe Endpoint $(H)$, Human Health (overall impact, point [Pt]) & $2.18 \mathrm{E}-03$ & $3.26 \mathrm{E}-03$ & \multirow{7}{*}{$\begin{array}{l}\text { 1-Windrow } \\
\text { 2-Windrow+Landfill }\end{array}$} \\
\hline Climate change Human Health [DALY] & $1.28 \mathrm{E}-03$ & $2.03 \mathrm{E}-03$ & \\
\hline Human toxicity [DALY] & $3.90 \mathrm{E}-06$ & $2.54 \mathrm{E}-05$ & \\
\hline Ionizing radiation [DALY] & 1.31E-08 & 3.09E-08 & \\
\hline Ozone depletion [DALY] & $1.89 \mathrm{E}-12$ & $7.72 \mathrm{E}-12$ & \\
\hline Particulate matter formation [DALY] & $8.89 \mathrm{E}-04$ & $1.20 \mathrm{E}-03$ & \\
\hline Photochemical oxidant formation [DALY] & $1.93 \mathrm{E}-08$ & $9.12 \mathrm{E}-08$ & \\
\hline ReCiPe Endpoint (H), Ecosystems (overall impact, point [Pt]) & $7.41 \mathrm{E}-06$ & $1.17 \mathrm{E}-05$ & \multirow[t]{10}{*}{$\begin{array}{l}\text { 1-Windrow } \\
\text { 2-Windrow+Landfill }\end{array}$} \\
\hline Agricultural land occupation [species.yr] & 0 & 0 & \\
\hline Climate change Ecosystems [species.yr] & $7.26 \mathrm{E}-06$ & $1.15 \mathrm{E}-05$ & \\
\hline Freshwater ecotoxicity [species.yr] & $7.39 \mathrm{E}-13$ & $3.73 E-12$ & \\
\hline Freshwater eutrophication [species.yr] & $2.83 \mathrm{E}-10$ & $2.85 \mathrm{E}-10$ & \\
\hline Marine ecotoxicity [species.yr] & $4.86 \mathrm{E}-15$ & $2.51 \mathrm{E}-14$ & \\
\hline Natural land transformation [species.yr] & 0 & 0 & \\
\hline Terrestrial acidification [species.yr] & $1.45 \mathrm{E}-07$ & $1.62 \mathrm{E}-07$ & \\
\hline Terrestrial ecotoxicity [species.yr] & $5.02 \mathrm{E}-10$ & 3.17E-09 & \\
\hline Urban land occupation [species.yr] & 0 & 0 & \\
\hline
\end{tabular}

*Pt: Point; DALY: Disability Adjusted Life Years; yr: Year 


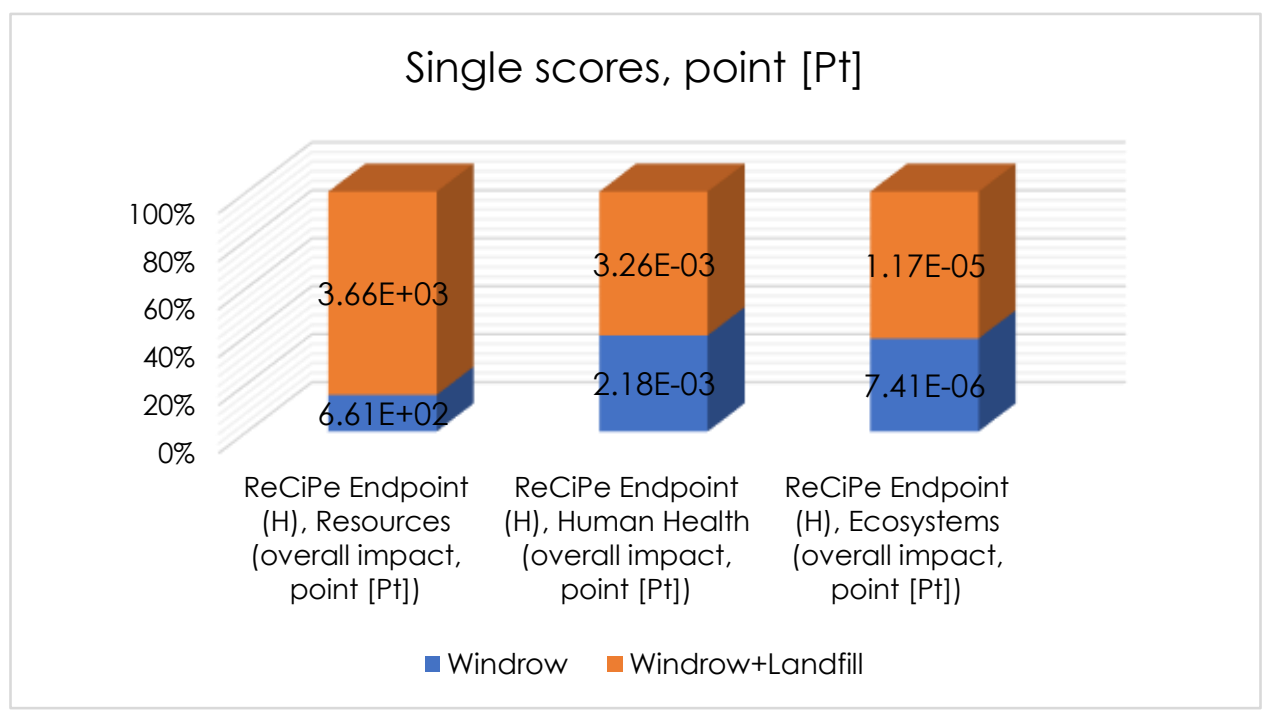

Figure 4 Single scores endpoint ReCiPe assessment for windrow, and hybrid_windrow with landfill

Sensitivity Analysis

The importance of sensitivity analysis (SA) in establishing the parameters and assumptions that have the strongest influence on a result cannot be overstated. SA is a tool for optimizing data collecting and analysis without compromising the reliability of the result [2]. The sensitivity study for aerobic windrow was examined in this section. To assess the sensitivity of each parameter, $10 \%$ of the input variations were employed. Table 4 displays the sensitivity values for GWP, FEP, ODP, FEP, TAP, POFP, and PMFP from aerobic windrow plants. As shown in Table 4, the resilience of five factors (diesel, energy, water, distance, and payload) was investigated. The parameter is considered to be sensitive when the proportion of variation is larger than $10 \%$. Based on the six impact groups employed for the SA, it was discovered that none of the parameters for FW treatment were identified as the most sensitive parameters since they had the lowest percentage of change of less than $10 \%$. Because all of the parameters are determined to be less than $10 \%$ of each impact category, this suggests that the parameters are less susceptible to the impact categories.

\section{Mitigation Strategies for Composting}

Composting mitigation options may involve the application of co-substrates (i.e., bulking materials, amendments, inoculation agents), an aeration system, a chemical, or maturing compost as a cover substance. Amongst these four mitigation techniques, using co-substrates, such as bulking materials (i.e., fly ash, bio-char, woodchips) lowered pollution levels the most as bulking materials encourage greater air circulation to the compost, control moisture, increase porosity, and structural support [8]. Saw dust usage, for example, would have the smallest GHG emission $\left(33 \mathrm{~kg} \mathrm{CO} 2\right.$ eq. $t^{-1}$ DM), but the aeration system that employs forced continuous aeration with lesser aeration, had the maximum reduction in $\mathrm{CH}_{4}$ emission [23], [24]. Zhang et al. [25] demonstrated that the highest mitigating efficiency for $\mathrm{CH}_{4}$ was achieved on the pile at the lowest height, while the highest intervention for $\mathrm{N}_{2} \mathrm{O}$ was achieved on the pile at the highest height. When using chemical or matured compost as a sheathing, combining and overlaying swine manure to mature compost has greatly decreased GHG emissions [26].

Table 4 Six impact groups sensitivity analysis for changes in windrow composting assessment

\begin{tabular}{|c|c|c|c|c|c|c|c|}
\hline $\begin{array}{l}\text { Percentage } \\
\text { of Variation } \\
(\%)\end{array}$ & $\begin{array}{l}\text { Input } \\
\text { Parameters }\end{array}$ & 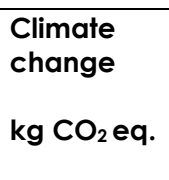 & $\begin{array}{l}\text { Freshwater } \\
\text { eutrophication } \\
\text { kg P eq. }\end{array}$ & $\begin{array}{l}\text { Ozone } \\
\text { depletion } \\
\text { kg CFC-11 } \\
\text { eq. }\end{array}$ & $\begin{array}{l}\text { Terrestrial } \\
\text { acidification } \\
\text { kg SO} \\
2 \text { eq. }\end{array}$ & $\begin{array}{l}\text { Photochemical } \\
\text { oxidant } \\
\text { formation } \\
\text { kg NMVOC } \\
\text { eq. }\end{array}$ & $\begin{array}{l}\text { Particulate } \\
\text { matter } \\
\text { formation } \\
\text { kg PM10 } \\
\text { eq. }\end{array}$ \\
\hline \multirow{3}{*}{$(+/-) 10 \%$} & Diesel (\%) & 0.000502 & 0.000553 & 0.055100 & 0.000136 & 0.003670 & 0.000236 \\
\hline & Electricity (\%) & 0.009510 & 0.000017 & 0.040200 & 0.001850 & 0.060500 & 0.005750 \\
\hline & Payload (\%) & 0.000049 & 0.000001 & 0.000153 & 0.000003 & 0.000127 & 0.000007 \\
\hline
\end{tabular}


In addition, the operational changes during the procedure (i.e., two-stage composting, temperature control) are one of the recommended strategies that have effectively decreased composting length, increased recalcitrant organic compounds such as lignin and cellulose transformation and improved product quality [27]. Whether the composting system is static or dynamic, an opened or closed system, operational procedures requiring electricity or fuel must always be designed to minimize the total environmental impact of the operation [28]. Wang et al. [29] inspected the influence of lime additives and struvite formation on odour-emitting annoyances formed during the windrow process treatment. They discovered that entrapping $\mathrm{NH}_{3}$ via struvite formation significantly decreased the highest odour unit of $\mathrm{NH}_{3}$ from $3.0 \times 10^{4}$ to $1.8 \times 10^{4}$ and in the treatment of phosphate salts addition with struvite formation, total bacterial variation was improved [29]. In comparison to semi-centralized recovery plants, centralized recovery plants would maximize GWP and land utilization [1]. A better on-site and decentralized management of $\mathrm{FW}$ is needed in terms of the reduction of waste to landfills and the effect on our environment that FW can have [1], [6]. However, landfill can be a better environmental scenario, when it has a mechanism for collecting and processing gases utilized for obtaining energy, resulting in a decrease in cumulative GHG impacts [12]. Mendes et al. [14] discovered that landfilling with energy recovery has marginally higher environmental benefits than landfilling without energy recovery. Furthermore, according to Hong et al. [30], electricity recovery from $\mathrm{CH}_{4}$ gas is the most important component in decreasing the potential consequences of global warming.

\subsection{CONCLUSION}

This study assessed the environmental impacts and benefits of two treatment scenarios for FW management-windrow composting and hybrid windrow composting with landfills-using LCA methodology. The scenario of real-scale composting was assessed for this study because specific waste data, which is generally difficult to acquire, was already obtainable from previous research, and partly since infrastructures for all scenarios currently exist and could be utilized to collect site-specific data. This provides insight into what higher management levels of the waste hierarchy, such as composting, have had to offer in the perspective of selecting current composting management preferences, as well as the methodological challenges encountered while evaluating FW composting management options in Malaysia. From this study, it can be concluded that windrow composting technology has a lower environmental impact and is a more environmentally friendly option than windrow composting combined with landfills based on the midpoint and single score endpoint results revealed. This is established by a large reduction in both miles and quantity of road transportation, considerably lower total operational energy requirements, and the conservation of resources toward compost created by the compostable material. Besides, the aerobic windrow system is preferred due to the low capital costs associated with site development, the purchase of a turner or tractor and screener, the installation of conveyance facilities, screening, and baggers. It may be an attractive alternative if the land is accessible and there is a substantial volume of waste to compost. The windrow composting technology can handle more than 10 tons of waste, and if the amendment is applied correctly, the composting time can be reduced by more than $30 \%$. Meanwhile, hybrid scenario_windrow composting combined with landfill had the largest negative environmental impact in all categories such as climate change (1.45E+03 kg CO $2 \mathrm{eq})$, freshwater ecotoxicity (1.31E$02 \mathrm{~kg}$ 1,4-DB eq); freshwater eutrophication (6.49E-03 $\mathrm{kg} \mathrm{P}$ eq); terrestrial acidification $(2.80 \mathrm{E}+01 \mathrm{~kg} \mathrm{SO} 2 \mathrm{eq})$, ozone depletion (4.39E-09kg CFC-11 eq), and classified as energy-consuming procedure with primary energy demand observed approximately 9141.24 MJ. In most categories, hybrid windrow composting with landfill technology gives the fewest benefits in the form of sustainability impact compared to windrow composting independently, specifically when GWP is taken into consideration. More research is needed to investigate different scales, operating systems, and waste streams in order to obtain more conclusive results from mitigation strategies.

\section{Acknowledgement}

This research is supported by the Malaysia Research University Network, under MRUN Grant No. R. J130000.7851.4L898.

\section{References}

[1] Brenes-Peralta, L., Jimenez-Morales, M. F., CamposRodriguez, R., De Menna, F., and Vittuari, M. 2020. Decision-making Process in the Circular Economy: A Case Study on University Food Waste-to-Energy Actions in Latin America. Energies. 13(9).

DOl: http://dx.doi.org/10.3390/en13092291.

[2] Al-Rumaihi, A., McKay, G., Mackey, H. R., and Al-Ansari. 2020. Environmental Impact Assessment of Food Waste Management Using Two Composting Technique. Sustainability. 12(4).

DOI: http://dx.doi.org/10.3390/su12041595.

[3] Keng, Z. X., Chong, S., Ng, C. G., Ridzuan, N. I., Hanson, S., Pan, G.-T., ... Lam, H. L. 2020. Community-scale Composting for Food Waste: A Life-cycle Assessmentsupported Case Study. Journal of Cleaner Production. 121220.

DOI: http://dx.doi.org/10.1016/j.jclepro.2020.121220. 
[4] Lim, L. Y., Bong, C. P. C., Lee, C. T., Klemes, J. J., Samidi M. R., and Lim, J. S. 2017. Review on the Current Composting Practices and the Potential of Improvement Using Twostage Composting. Chemical Engineering Transactions. 61: 1051-1056.

DOI: http://dx.doi.org/10.3303/CET1761173

[5] Barth, J. 2009. Survey on Biological Waste Treatment in Europe. Weimar ORBIT/ECN.

Retrieved online 10/6/2021 at: http://www.organicsrecycling.org.uk/dmdocuments/compostproduction_and _usein_EU.pdf.

[6] Righi, S., Oliviero, L., Pedrini, M., Buscaroli, A., and Della Casa, C. 2013. Life Cycle Assessment of Management Systems for Sewage Sludge and Food Waste: Centralized and Decentralized Approaches. Journal of Cleaner Production. 44: 8-17.

DOI: http://dx.doi.org/10.1016/j.jclepro.2012.12.004.

[7] Andersen, J. K., Boldrin, A., Christensen, T. H., and Scheutz, C. 2012. Home Composting as an Alternative Treatment Option for Organic Household Waste in Denmark: An Environmental Assessment Using Life Cycle AssessmentModelling. Waste Management. 32(1): 31-40. DOl: http://dx.doi.org/10.1016/j.wasman.2011.09.014.

[8] Bong, C. P. C., Lim, L. Y., Ho, W. S., Lim, J. S., Klemeš, J. J., Towprayoon, S., ... Lee, C. T. 2017. A Review on The Global Warming Potential of Cleaner Composting and Mitigation Strategies. Journal of Cleaner Production. 146: 149-157. DOl: http://dx.doi.org/10.1016/j.jclepro.2016.07.066.

[9] Amlinger, F., Peyr, S., and Cuhls, C. 2008. Greenhouse Gas Emissions from Composting and Mechanical Biological Treatment. Waste Management and Research. 26(1): 4760. DOI: http://dx.doi.org/10.1177/0734242x07088432.

[10] Boldrin, A., Andersen, J. K., Møller, J., Christensen, T. H. and Favoino, E. 2009. Composting and Compost Utilization: Accounting of Greenhouse Gases and Global Warming Contributions. Waste Management and Research. 27(8): 800-812.

DOI: http://dx.doi.org/10.1 177/0734242×09345275.

[11] Yoshikawa, N., Matsuda, T., and Amano, K. 2021. Life Cycle Environmental and Economic Impact of a Food Waste Recycling-farming System: A Case Study of Organic Vegetable Farming in Japan. International Journal Life Cycle Assessment. 0123456789 DOI : http://dx.doi.org/10.1007/s11367-021-01879-0.

[12] Abduli, M. A., Naghib, A., Yonesi, M., and Akbari, A. 2010 Life Cycle Assessment (LCA) Of Solid Waste Management Strategies in Tehran: Landfill and Composting Plus Landfill. Environmental Monitoring and Assessment. 178(1-4): 487498.

DOI: http://dx.doi.org/10.1007/s10661-010-1707-x.

[13] Ghazvinei, P. T., Mir, M. A., Darvishi, H. H., and Ariffin, J. 2017. University Campus Solid Waste Management. Springer Briefs in Environmental Science.

DOI: http://dx.doi.org/10.1007/978-3-319-43228-1.

[14] Mendes, M. R., Aramaki, T., and Hanaki, K. 2004. Comparison of the Environmental Impact of Incineration and Landfilling in São Paulo City as Determined by LCA. Resources, Conservation and Recycling. 41 (1): 47-63. DOI: http://dx.doi.org/10.1016/j.resconrec.2003.08.003.

[15] Johari, A., Ahmed, S. I., Hashim, H., Alkali, H., and Ramli, M. 2012. Economic and Environmental Benefits of Landfill Gas from Municipal Solid Waste in Malaysia. Renewable and Sustainable Energy Reviews. 16(5): 2907-2912. DOI: http://dx.doi.org/10.1016/j.rser.2012.02.005

[16] Agamuthu, P. and Fauziah, S. H. 2008. Solid Waste: Environmental Factors and Health. Proceedings of the 2008. 2008: 1-50.
[17] Hong, R. J., Wang, G. F., Guo, R. Z., Cheng, X., Liu, Q. Zhang, P. J., and Qian, G. R. 2006. Life Cycle Assessment of BMT-based Integrated Municipal Solid Waste Management: Case Study in Pudong, China. Resources, Conservation and Recycling. 49(2): 129-146. DOI: http://dx.doi.org/10.1016/j.resconrec.2006.03.007.

[18] Forti, M., Hansen, S. B., Kirkeby, J. T., Agamuthu, P., And Christensen, T. H. 2004. Environmental Assessment of Household Waste Disposal in Kuala Lumpur. Malaysian Journal of Science. Series A: Life Sciences. 23: 115-123.

[19] Hauschild, M. Z., Rosenbaum, R. K., and Olsen, S. I. (Eds.). 2018. Life Cycle Assessment: Theory and Practice. Springer Nature. DOI: http://dx.doi.org/10.1007/978-3-319-56475-3.

[20] Cavalett, O., Chagas, M. F., Seabra, J. E. A., and Bonomi, A. 2012. Comparative LCA of Ethanol Versus Gasoline in Brazil Using Different LCIA Methods. The International Journal of Life Cycle Assessment. 18(3): 647-658. DOI: http://dx.doi.org/10.1007/s1 1367-012-0465-0.

[21] Poeschl, M., Ward, S., and Owende, P. 2012. Environmental Impacts of Biogas Deployment - Part II: Life Cycle Assessment of Multiple Production and Utilization Pathways. Journal of Cleaner Production. 24: 184-201. DOI: http://dx.doi.org/10.1016/j.jclepro.2011.10.030.

[22] Abba, A. H. 2014. Assessment of Municipal Solid Waste Disposal Options Using Analytical Hierarchy Process and Life Cycle Analysis. Doctoral Dissertation. Universiti Teknologi Malaysia.

[23] Yang, F., Li, G. X., Yang, Q. Y., and Luo, W. H. (2013). Effect of Bulking Agents on Maturity and Gaseous Emissions During Kitchen Waste Composting. Chemosphere. 93(7): 1393-1399.

DOI: http://dx.doi.org/10.1016/j.chemosphere.2013.07.002.

[24] Jiang, T., Li, G., Tang, Q., Ma, X., Wang, G., and Schuchardt, F. 2015. Effects of Aeration Method and Aeration Rate on Greenhouse Gas Emissions During Composting of Pig Feces in Pilot Scale. Journal of Environmental Sciences. 31: 124-132. DOI: http://dx.doi.org/10.1016/j.jes.2014.12.005.

[25] Zhang, H., Li, C., Li, G., Zang, B., and Yang, Q. (2012). Effect of Spent Air Reusing (SAR) on Maturity and Greenhouse Gas Emissions during Municipal Solid Waste (MSW) Composting-with Different Pile Height. Procedia Environmental Sciences. 16: 59-69. DOI: http://dx.doi.org/10.1016/j.proenv.2012.10.009

[26] Luo, W. H., Yuan, J., Luo, Y. M., Li, G. X., Nghiem, L. D., and Price, W. E. 2014. Effects of Mixing and Covering with Mature Compost on Gaseous Emissions during Composting. Chemosphere. 117: 14-19. DOI: http://dx.doi.org/10.1016/j.chemosphere.2014.05.043.

[27] Reyes-Torres, M., Oviedo-Ocaña, E. R., Dominguez, I., Komilis, D., and Sánchez, A. 2018. A Systematic Review on the Composting of Green Waste: Feedstock Quality and Optimization Strategies. Waste Management. 77: 486-499. DOI: http://dx.doi.org/10.1016/j.wasman.2018.04.037.

[28] Sánchez, A., Artola, A., Font, X., Gea, T., Barrena, R. Gabriel, D., ... Mondini, C. 2015. Greenhouse Gas from Organic Waste Composting: Emissions and Measurement. $\mathrm{CO}_{2}$ Sequestration, Biofuels and Depollution. 33-70. DOI: http://dx.doi.org/10.1007/978-3-319-11906-9_2.

[29] Wang, X., Selvam, A., Lau, S. S. S., and Wong, J. W. C. 2018. Influence of Lime and Struvite on Microbial Community Succession and Odour Emission during Food Waste Composting. Bioresource Technology. 247: 652-659. DOI: http://dx.doi.org/10.1016/j.biortech.2017.07.091.

[30] Hong, J., Li, X., and Zhaojie, C. 2010. Life Cycle Assessment of Four Municipal Solid Waste Management Scenarios in China. Waste Management. 30(11): 2362-2369. DOI: http://dx.doi.org/10.1016/j.wasman.2010.03.038. 